\title{
TA'ARUF LOCALITY: INTEGRATION OF \\ ISLAMIC LAW AND CUSTOMARY LAW OF THE PHENOMENON USING TRIBE GREDOAN IN BANYUWANGI
}

\author{
Qurrotul Ainiyah \\ ainishomad27@gmail.com \\ S3 UIN Walisongo Semarang dan IAI Al Falah As Suniyyah Kencong Jember
}

\begin{abstract}
This research is a study which used a qualitative approach with the type field research, which is related to the Gredoan tradition as the event of looking for a life partner in using community located on Macan Putih Village, Kabat district in banyuwangi. In this paper will explain how is the custom to find a mate in Banyuwangi society that has lasted since long ago. Gredoan is the relations between customary law and Islamic law which seeks to integrate between the customary laws with Islamic law in matters of marriage. the Contributions of research are: First, there is public space in the form of practice the ta'aruf process towards marriage in Banyuwangi Using society which known as gredoan custom. Second, that Islamic law turns out to have spaces to accommodate the customs as the joints of Islamic law. gredoan Tradition as an al-"urf in using community of banyuwangi in ta'aruf process towards marriage, it obtains legitimacy by the maqāșid al-syarī' ah which is based on the rules is al-'âdat al-Muhakkamah.
\end{abstract}

Key Word: Islamic Law, Customary Law, Gredoan

\section{Introduction}

Indonesia has a variety of cultural customs and customary law, the diversity of cultural customs and customary law in Indonesia due to the the historical development of the culture from the polonesia Malay times with social life, place of residence and their environment are different. In life of the Indonesia people are also affected both Hindu religious traditions, Islam, and Christianity. By the birth of Indonesia Rebuplik, it realizes the ideal of the various customs people that are different, so that, it becomes "Bhinaeka Tunggal Ika" eventhough different is integrated in the container of Pancasila state. ${ }^{1}$

The custom diversity also implicate in ordinance of marriage in customary law communities Indonesia, for example, the tradition of Merari sasak in Lombok, ngunduh mantu tradition in java, the tradition of kawin colongan in banyuwangi and others. There are also some cultural traditions that regulate the process before marriage. One of them is gredoan, this is a tradition ofmatchmaker event in using area banyuwangi.

Whereas in Islam, has ethics in the

\begin{tabular}{lll}
\hline \multicolumn{1}{c}{ Hilman } & Hadikususma, & Hukum \\
Perkawinan Adat, & (Bandung: Citra & Aditya \\
Bakti,1999) 12. & &
\end{tabular}

Ta'aruf Locality: Integration Of Islamic Law And Customary Law Of The Phenomenon Using Tribe Gredoan In Banyuwangi 
association and conduct the introduction between man and woman before heading marriage. That is a process which is known as ta'aruf or introduction. Ta'aruf in Islam is the process to get to know the personality, social background, culture, education, family, and religion both sides. By keeping the dignity of a human being exalted of Allah, it means not to fall on indecent behavior, it can be forwarded to know each individual family circumstances, for example by silaturrahmi to both parents. ${ }^{2}$

Ta'aruf with silaturrahmi is done for consideration for the related before deciding to live together. For that purposes, Islam provides an opportunity to see and identify the candidate. ${ }^{3}$ By giving boundaries in relationships between man with woman. For example, the prohibition to approach adultery. ${ }^{4}$ There are several types of ta'aruf processes which commonly encountered in 'urf in the Community: First, find a mate by himself, Second, betrothed by the family either as a child or a grown, third, directly from one side groom bride, fourth; matchmaking via intermediaries, such as through a third side whom he trusted as well as matchmaking. And several regions in Indonesia have unique tradition in terms of finding a mate or matchmaking. One of them that exist in the community is in using Banyuwangi, the process of finding a mate or matchmaking is done with a tradition, namely; Gredoan tradition, Bathokan, and

\footnotetext{
2 Tihami, Fikih Munakahat, ( Jakarta : PT RajaGrafindo Persada 2010) 23.

3 Rahmat Hakim, Hukum Perkawinan Islam (Bandung : CV Pustaka Setia, 2000), 44.

${ }^{4}$ Tihami, Fikih Munakahat, 22.
}

Mlayokaken. But among three traditions are still maintained and preserved till this day is a tradition Gredoan.

Gredoan is the custom of finding mate in Macan Putih Village Kabat District of Banyuwangi, Gredoan held every year coincide with the commemoration of Prophet Muhammad's Birthday which is always held on a large scale and is the largest maulid celebrations in the district of Banyuwangi. ${ }^{5}$ using Peoples in Banyuwangi have faith that in the month of maulid is a good month to find a mate and do the marriages for young couples who have been quite old. Because doing marriages for young people who are old enough and ready to go to the level of marriage is also considered to have followed the Sunnah of the Prophet. ${ }^{6}$

This paper intends to explore the concept of ta'aruf locality in view of customary law and Islamic law by raising using tribal cultural phenomenon in Banyuwangi that is Gredoan tradition. The questions to be answered in this paper are; How do the practice of ta'aruf process in Gredoan tradition in the community of using Kabat District of Banyuwangi? how to integrate between Islamic law and customary laws that occurred in Gredoan tradition ?. To answer these questions, the next part of this paper are; the first discussion will attempt to examine the discourse about ta'aruf as the tradition towards marriage. The second part will discuss Gredoan as local traditions and communities of using in Banyuwangi

5 Dwi Pranoto, Membicarakan Seni Dan Sastra Banyuwangi (Bali : Pustaka Larasan, 2014), 77.

\footnotetext{
${ }^{6}$ Pranoto, Membicarakan Seni, 77.
} 
Finally, this paper will conclude with a discussion of the integration of Islamic law with customary law in gredoan tradition.

\section{Theoretical Framework \\ Ta'aruf as a 'Urf Toward Marriages}

The word al- 'urf is derived from the word 'arafa, which has a derivation of the word "al-ma'ruf" which means something known or unknown. ${ }^{7}$ Etymologically means something to be good and accepted by common sense. ${ }^{8}$ In harfiyah, al- 'urf is a state, sayings, deeds, or provisions that has been known to mankind and has become a tradition to carry it out or leave it. Among the people, al-'urf is often called as customs ${ }^{9}$ in other words there is no difference between al-urf and customs. between both of them do not contain significance customs and al-urf is terminological which have no differences of principle. ${ }^{10}$ For example, in the book of fiqh, there are expressions hadhâ Thabit al-'urf bi wa al-'adah (provision was based al-'urf and al-'adâh), then the intended meaning of both are the same. Mentioning al-adat after the word al-'urf serves as reinforcement ( $t a^{\prime} k i d$ ) only, instead of separate sentences that contain different meanings (ta'sis)..$^{11}$

Generally al-'urf is practiced by all scholars of fiqh, particularly from the madhab of Hanafiyya and Malikiyyah.

\footnotetext{
${ }^{7}$ Amir Syarifuddi, Ușûl Fiqh, Jilild 2

(Jakarta: Logos wacana ilmu 2001) 363

8 Satria Effendi, Ushul Fiqh (Jakarta : Kencana, 2009), 153.

${ }^{9}$ Rahcmat Syafe'i, Ilmu Ushul Fiqh

(Bandung : CV Pustaka Setia, 2007), 128.

${ }^{10}$ Abdul Wahhab Khallaf, Ilm Ușûl Fiqh,

(Qahirah: Dar al-Qalam, tt) 89

${ }^{11}$ Abdul Karim Zaidan, al- Wajiz Fi Ușûl

al-Fiqh, (kairo: Dhar al-Fikr,tt) 155
}

Ta'aruf Locality: Integration Of Islamic Law And Customary Law Of The Phenomenon Using Tribe
Ulama' Hanafiyyah uses istihsan (one of the method of ijtihad that takes something better which is not regulated by the Personality') in ijtihad, and one of the istihsan is istihsan al-'urf is taken precedence over qiyas khafi (qiyas light) and also is taken precedence over nash common, Malikiyyah makes al- 'urf in the form of muamalah (relationship interests), which has become customary and has been steady (constant) in the middle of the medina community.

Syafi'iyyah uses al-'urf in things that do not find provisions limit in Personality 'nor the use of language. In response to the use of al- 'urf in fiqh, al-Suyûti reviews it by returning to the rule of al-'âdah muhakkamah. The position of al-'urf (custom, tradition, the conventional rule of community) is the level of importance not only in the implementation of Islamic law , but all of the legal system which exist in the world awakened, set and system according to the logic of the law a little more continuously consider al-'urf is a universal and essential element in any development of the law.

In general, - is divided into two parts, first is al-'urf șahîh, namely - a habit which is known to mankind and not contrary to the laws of Personality '. Second - fasîd, a a habit which is known to human, and contrary to the laws of Personality. ${ }^{12}$ the meaning of this division according to the scholars is that customs and al-'urf can be used as a backrest to establish law syarīah if there is no nash syarī'ah or lafad sharih (firmly) that opposed to it.

\footnotetext{
${ }^{12}$ Abdul Wahhab, Ilm Ushul Fiqh, 88
} Gredoan In Banyuwangi 
The use of al-'urf in fiqh,, Al-Şuyûti reviews it by returning to the rule: al-'âdah muhakamah "Custom or tradition (good) can be used as a reference of law". The rule about this custom is a source of Islamic law which is aspirational, accommodating and flexible. The tradition of a society can flourish, different, and change according to the increase in economic, social, and political education of its citizens. Such changes make the law must be pro-active to guard them, so it is not out of date. This rule in order to deliver the substance of the application of Islamic law which have to bring the mission which is to create maşâlih al-'ibâd (benefit servants). The benefit is something that encourages the good (positive), and avoid the badness that encourages the badness (negative). ${ }^{13}$

Furthermore about the tradition, R. Redfield as quoted Bambang Pranowo said that the concept of tradition is divided into two, namely great traditions and the small tradition (little tradition). This concept depicts that in a human civilization there must be two kinds of tradition which are categorized as a great tradition and little tradition. Little tradition is a tradition of their own who like to think and by itself covers a relatively small number of people. While the great tradition is a tradition that comes from the majority of people who never thought deeply on the traditions they already have. Traditions that exist in philosophers, clerics, and intellectuals is a tradition instilled with full awareness, while tradition of most people is a tradition

\footnotetext{
${ }^{13}$ M. Maftuhin ar-Raudli, Kaidah Fiqih Menjawab Problematika Sepanjang Zaman (Yogyakarta : Gava Media, 2015), 202.
}

Ta'aruf Locality: Integration Of Islamic Law And Customary Law Of The Phenomenon Using Tribe Gredoan In Banyuwangi

which is received from the first with what is (taken for granted) and never examined or filtered the development. ${ }^{14}$ While the concept of Islam included in the scope of its use, 'custom or al-urf which is divided into two parts:

a) Al-'urf 'Amm (a common habit), namely a habit which has been prevailing everywhere, almost anywhere in the world, regardless of country, nation, and religion. For example nodding their heads means approved and shook their heads means refuse or revoke, when people do the opposite of that, it is considered strange or odd.

b) Al-'urf Khas (special custom), namely custom which is made by group of people in a particular place or at a particular time; is not applicable in all places and at any time. For example: 'the customary to pull lineage through the mother or female (matrilineal) in Minangkabau and through the father (patrilineal) among the Batak tribe. $^{15}$

Formulating theories about al-'urf as described above, it will be associated with ta'aruf; meant here, a process of introduction between man and woman towards marriage. While the meaning of ta'aruf is silaturahmi that created between any two or more people for a specific purpose, can be a friendship, brotherhood,

\footnotetext{
Antara Tradisi Dan Relasi Kuasa (Yogyakarta: Adicita Karya Nusa, 1998), 3.

${ }^{15}$ Amir Syarifuddin, Ushul Fiqh Jilid 2 (Jakarta : Kencana, 2011), 391
}

14 Bambang Pranowo, Islam Factual 
marriage and others. ${ }^{16}$ Ta'aruf (introduction) is part of the Muslim brotherhood, in Islam is highly recommended for his community to mutually do ta'aruf each other. Furthermore, in its development, the meaning of ta'aruf according to al- 'urf of Indonesian society narrowed to the introduction between men and woman in search of a life partner.

Ta'aruf process or this introduction is the part that plays a very important of the whole process of marriage. Because, if someone who will foster home, he/she must recognize and know the identity of the prospective life partner. Thus, ta'aruf or introduction serves as an assessment process for prospective couples to know each other before arriving at the process of khitbah (woo). And it can be concluded that ta'aruf is the way or the correct way in accordance the human dignity to recognize mate in person. ${ }^{17}$

Islam allows a meeting between man and woman non-mahram within the bounds of reasonableness which allowed in Syarī'ah. Sometimes, a meeting between man and woman becomes a requirement when aiming for good, as to tholabul 'ilmi, doing good deeds, struggle, or other jobs that require between man and woman are in one room. ${ }^{18}$ Whereas when ta'aruf for the benefit to recognize a potential life

${ }^{16}$ Honey Miftahul jannah, A-Z Ta'aruf, Khitbah, Nikah, \& Talak Bagi Muslimah (Jakarta : PT Grasindo, 2014), 12.

${ }^{17}$ Ilham Abdullah, Kado Buat Mempelai : Membentuk Keluarga Sakinah, Mawaddah Wa Rahmah (Yogyakarta : Absolut, 2003), 218.

${ }^{18}$ Yusuf Al-Qaradhawi, Fatwa-fatwa Kontemporer Jilid 2 (Jakarta : Gema Insani, 1995), 392. partner, there are some things that are governed by Islam include:

1. Maintaining the view and breathtaking from the prohibited matters that kind of immoral which is called zina of the eyes (lahadhah). Not just the eye, lahadhah is the source of ittijah (orientation) glory, as well an ambassador also of lust. Someone who maintains his/her view, it means he maintains his genitalia.${ }^{19}$ The purpose of maintaining heart and the view is seeing the opposite sex with no passion or lust eyes, because there is essentially immoral acts and crime mostly stems from the eye. That is why, Allah first ordered to close the eyes before the maintaining the honor. ${ }^{20}$

2. Not doing khalawat together between man and woman who is not mahram in a quiet place or hidden, utter obscene speech in women who are not mahram and avoid physical contact

3. The existence of Mediator; namely an intermediary, can come from relatives or others, in the present, mediator can also come from social media and so forth. In addition, one party may bring their own or consider the prospective parents intermediary which is submitted along with the appropriate essential requirements as intermediary. ${ }^{21}$

\footnotetext{
${ }^{19}$ Rahman, Hudud dan Kewarisan (Jakarta : PT Raja Grafindo, 1996), 34.

20 Ibnul Qayyim al-Jauziyah, Jangan Dekati Zina (Jakarta : Pustaka Amani, 1995), 174.

${ }^{21}$ Abdullah, Kado Buat Mempelai, 225.
}

Ta'aruf Locality: Integration Of Islamic Law And Customary Law Of The Phenomenon Using Tribe Gredoan In Banyuwangi 
4. If after finishing ta'aruf immediately khitbah, man asks woman to be his wife, in ways that prevailing in society ${ }^{22}$ with certain boundaries, as the words of the Prophet .: "From Mughirah bin Shu'bah, in fact he has applied for a woman, and the Prophet said to him: "sight to him as such it will perpetuate the affection between both of you." 23

So, ta'aruf as a process leading to marriage is an al-'urf which could serve as the basis or source of the development of Islamic law, the scholars agree that the laws which were established based on al'urf last for al-urf changed, then the power the law was changed. In other words, that the provisions of Islamic law that builds on the al-urf not have a lasting ordinance.

\section{Methods}

Methodologically, this study uses a phenomenological quality approach to understand the conditions and characteristics of the people who make a mate search in Banyuwangi by examining the phenomenon of the Gredoan tradition in the Banyuwangi osing community for each individual. ${ }^{24}$ This research is a field research that comes directly to the object or location of the research, namely by

${ }^{22}$ Tihami, Fikih Munakahat, 24.

${ }^{23}$ Imam Tirmidzi, al-Jami' as-Şahih wa Huwa Sunan Tirmidzi : Abwâb an-Nikah (Beirut : Dar al-Fikr, 1983), 1093.

${ }^{24}$ John W. Creswell, Research Design: PendekatanMetodeKualitatif, Kuantitatif dan Campuran, translated by Achmad Fawaid and Rianayati Kusmini Pancasari, ( Yogyakarta: PutakaPelajar, 2016), 250 directly approaching the informants. ${ }^{25}$ This is done in order to obtain data relating to the tradition of kawincolong in the community using Banyuwangi. Observation, Interview and Documentation are the main data collection methods used in this study.

The data analysis technique that will be used is the analysis of significant statements, the formation of units of meaning, and the development of essay essences. ${ }^{26}$ Data analysis is carried out in preparing preliminary studies and theorizing before entering the field. Meanwhile, data analysis during the field is carried out on the temporary data obtained, that is using an interactive model. ${ }^{27}$ Then, analyzing the data after in the field after the data is collected.

To test the validity of the data, the researcher will use two methods; those are source triangulation and extension of participation. By using source triangulation, the researcher will test the credibility of data by comparing each information obtained through interview and observation techniques. While the technique of extension of participation ${ }^{28}$ will be used when there is a need to do double check the degree of data saturation.

${ }^{25}$ J. Supranto, Metode Riset :Aplikasinya Dalam Pemasaran(Jakarta : RinekaCipta, 2003), 28.

${ }^{26}$ Creswell, Research Design, 262

27 Data analysis of interactive models consists of three stages, namely (1) data reduction, (2) data display and (3) conclusions. See Sugiyono, Metode Penelitian Pendidikan : Pendekatan Kuantitatif, Kualitatif dan $R \& D$ ( Bandung : Alfabeta,2010), 338.

28 According to Bungin, the longer the researcher is in the field, the more informants will be and the more information will be obtained. See Supranto, Metode Riset 254.

Ta'aruf Locality: Integration Of Islamic Law And Customary Law Of The Phenomenon Using Tribe Gredoan In Banyuwangi 
Gredoan in using language means teasing $($ Nggridu $=$ nggoda $)$ or can be understood as a mechanism of local culture in the process of temptation to the opposite sex. However, Gredoan becomes unique when it becomes a tradition that is carried out as a search event a soul mate or matchmaking precisely in Macan Putih Village, District of Kabat Banyuwangi, Gredoan held every year in conjunction with the celebration of Prophet Muhammad's Birthday which is always held on a large scale and it is The Largest maulid celebrations in the district of Banyuwangi. ${ }^{29}$

The Gredoan process has been started since a few days before a series of commemorative events of maulid celebration of Prophet Muhammad. using people in Macan Putih village Kabat Banyuwangi districts have already started to prepare a variety of things that are needed, including dishes that will be served to the guests. Therefore, many families are deliberately inviting relatives from both inside and outside the village especially those still unmarried to come help. So that, at these moments arise many new faces which used by the young people as a place to find a mate. ${ }^{30}$ Another interesting thing is that Banyuwangi people believe that in the month of maulid is a good month to find a mate and do marriages for young couples that have been quite old. Because doing marriages

${ }^{29}$ Dwi Pranoto, Membicarakan Seni Dan Sastra Banyuwangi (Bali : Pustaka Larasan, 2014), 77.

${ }^{30}$ Eko Budi Setianto, Bunga Rampai Ritual Adat Dan Tradisi Masyarakat Banyuwangi (Banyuwangi : Dinas Kebudayaan Dan Pariwisata Kabupaten Banyuwangi), 37.

Ta'aruf Locality: Integration Of Islamic Law And Customary Law Of The Phenomenon Using Tribe for young people who are old enough and ready to go to the level of marriage is also considered to have followed the Sunnah of the Prophet. ${ }^{31}$

It can not be certained when the first time a tradition Gredoan start, from the observation in macan putih village the findings researchers only an estimate, as the narrative of Mr. Joko as community leaders and also chairman POKDARWIS (Awareness Group Travel) in Macan Putih village District of Kabat Banyuwangi that the notion of tradition Gredoan:

About when exactly the appearance of it, no one can be sure, but there is an estimate that has been around since 1960, there also said that before independence was already there. and along with the times and technological advancement of this tradition is different from the first, in terms of both process and communication equipment. $^{32}$

From the narrative of Mr. Joko above, the certainty of Gredoan tradition can not be ascertained, it is estimated to have existed since 1960, but there is an also said since before the independence of the Republic of Indonesia this tradition has existed. At first, Gredoan is not a tradition that only done to coincide with the birthday of Prophet Muhammad, but Gredoan is usually done anytime between young people who want to get a pair and do at night, as expressed by Mr Safari one of the community elders in Macan Putih village Kabat District of Banyuwangi:

Long time ago, Gredoan not only occur at

\footnotetext{
${ }^{31}$ Pranoto, Membicarakan Seni, 77.

32 Joko, Wawancara, Macan Putih, 15 Juni 2016.
} Gredoan In Banyuwangi 
a time of maulidan, anytime could happen Gredoan. When I was younger, if someone had acquaintances in the village or in another village, then the male come to woman home, in the outside, peering out from behind the hut while providing sodho. after that, there was a conversation between the two if a woman responds the seduction from the man it will continue to stage khitbah and marriage subsequent. ${ }^{33}$

Initially, Gredoan process carried out by young people who want to get a mate with a bounded wall made by bamboo, using communication tools such as sodho / stick. This explanation is reinforced by $\mathrm{Mr}$. Wahyudi, he is one of the residents Macan Putih Kabat District of Banyuwangi:

Iku bien awalê Gredoan, kan pas maulidan wong-wong iku benginê padha olah-olahan kanggo gawe panganan ring dina kesuk. Ring endi bain umah hang ana perawan mesti akeh diparani lancing hang arep Gredhoan. Mula iku umah hang sing duwe anak perawan biasane ditekani sanak keluarga hang magih perawan teka desa liya. Trus biyen kan umah e iku sek teko gedhek, dadi lancing-lancingê hang arep gredo iku intip-intip teko njobo, ambi nganggo sodho iku, di lebokakên nang bolongane. ${ }^{34}$

(Gredoan occurred at the time of the Prophet Muhammad's birthday, on the evening most people are busy making food for the next day. In every house, there is definitely daughter who was a girl who later visited by many youth who will tease

\footnotetext{
Juni 2016.

${ }^{33}$ Safari, wawancara, Macan Putih, 15 2016.

${ }^{34}$ Yudi, wawancara, Macan Putih, 15 Juni
}

(gudho). If there is one house that did not have a girl ,then, they will bring a relative who is still a girl from another village. on that period, the wall was made from bamboo, so that the youth peeking from the outside by using a stick and is inserted into the hole bamboo).

But with the development of the times and the rapid advancement of technology, the tradition Gredoan has changed considerably, including a communication tool for process (nggridu) no longer use sodho or stick due to house building of societies are not made like a huts but has been in the form of the building, so that, now the perpetrators of this tradition choose to meet in person or using a mobile phone. In addition, the youth and the girl who follows a tradition now more free to interact and conduct the introduction or in the religion of Islam, better known as ta'aruf. However, despite this tradition has changed much, Macan putih people still preserve and maintain this Gredoan tradition . even, they consider that this tradition is one of the dignified tradition of arranged marriages. Furthermore Gredoan becomes a tradition which held in conjunction with the birthday of the Prophet Muhammad. ${ }^{35}$

Sakniki mlebet pun teng griyane, gawe nopo intip-intip,? langsung mertamu lan kenalan mawon, wong masak niku di tunggoni, trus kenalan, besoknya bisa di lanjut. waktu niku insun mertamu teng nggene (istri) trus kenal trus lanjut, langsung teng griyone ibu e. Nggeh orang tua pas waktu gredoan mboten melarang ada tamu yen medayoh. Di ajak ngobrol

${ }^{35}$ Sahilun A. Nasir, Tradisi Gredoan, 49.

Ta'aruf Locality: Integration Of Islamic Law And Customary Law Of The Phenomenon Using Tribe Gredoan In Banyuwangi 
kaleh tiang sepah e kedap terus di tinggal nerusne masak soale kang sek repot masak pas dalu niko. Kulo nggeh perkenalan, lanjut menyambung, trus langsung njaluk, proses e mboten dangu. Pas niku nggeh seng diomongne nggeh tanglet-tanglet tentang larene pun. ${ }^{36}$

(it straights now into his house, why should peek? immediately visit and acquaintance. When the girl to cook, male approaches then makes introductions, the next can be continued to apply to her parents' house. Parents do not prohibit period if there is a guest. the Guest is invited to talk with his parents in staying briefly then continue to cook for on the night it was still a hassle-troublesome. So I introduce, connect and then apply, the process is not long. When the discussion was everything about his personal)

yo tepak pas Gredoan, kenalan telung ndino langsung dadi.Trus mari kenalan mrene maneh, trus neng wong tuwek, dadi wes, seng kari dowo. Biyen pas gudo iku, di delok KTP-ne, seng lancing ta grong, endi KTP ne. iki lancing, mulo kedigu pas muludan gudone, trus yo isun kekno, Trus sesok e teko wong tuwekê, yo seneng, ketemune pas rame-rame iko, yo aran e wes jodho. Entuk barokah e kanjeng Nabi. ${ }^{37}$

(yes coincidence that gredoan time, introductions for 3 days later so (married). After that, it returned to the house directly to the parents, so the process is not long. When the Gredoan process, checked my identity card, viewed as a girl or not, ask

\footnotetext{
${ }^{36}$ Abdul Halim, Wawancara, Macan Putih, 16 Juni 2016.

${ }^{37}$ Muawanah, Wawancara, Macan Putih, 16 Juni 2016.
}

for identity card, then yes I give it . Indeed, such a fitting Gredo Prophet Muhammad's Birthday, then the next day to the parents, yes, i'm happy, the meeting when the show-do, yes as it's called soul mate, get a blessing from the Prophet Muhammad)

The description above, is the result of the interview with the doer of gredoan custom in contemporary times, basically the purpose of Gredoan tradition is as a matchmaking tool for the young people who are looking for life partner to make introductions so they can go into marriage. This tradition has been handed down, and not a few people of using who get a mate from Gredoan tradition, the tradition is still preserved today. Gredoan tradition is also one asset of Banyuwangi cultural customs that are different from the other regions.

In the teaching of Islam, the tradition of arranged marriages known as ta'aruf, ta'aruf in Islam certainly has norms to be observed in accordance with the norms of Islamic Syarī' ${ }^{`}$ ah is manners which related to meetings and association of man and woman when doing ta'aruf process. In Islamic law ta'aruf is' al-'urf al-șahîh (habits are considered valid) with the rules of fiqh al-'âdah muhakammah (Traditional habits can be (considered) law). Next, This paper will discuss the Gredoan tradition as ta'aruf locality to integrate law of custom with al-'urf and rules of fiqih that relied upon in examining Gredoan the tradition when viewed from the perspective of Islamic law.

\section{Integration of Traditional Law and Islamic Law in the phenomenon of Gredoan}

In view of customary law ta'aruf

Ta'aruf Locality: Integration Of Islamic Law And Customary Law Of The Phenomenon Using Tribe Gredoan In Banyuwangi 
process is called, in general, Pinangan acts on the flunky girls means heading to a wedding is an act that is not in violation of customary law. Gredoan tradition is a tradition of for the community in Macan Putih village Using Kabat District of Banyuwangi is maintained and preserved until today, but along with the times and the rapid advancement of technology, this tradition has many changes in its implementation. $^{38}$

Is a change in the process of implementation of the Gredoan custom from the past until now: First, communication media, if the first communication, in the Gredoan customs to the opposite sex by using sodho or stick and bounded by walls which were made of bamboo (gedhek), if the application the young man received the sodho will remain intact and vice versa if the application is rejected then sodho will be broken by the woman. But this time the young people prefer to meet in person or using a mobile phone or social media as a communication media. Second, the process ta'aruf in customs Gredoan formerly carried out by the young people in a way peep girls who are helping to cook in the kitchen from behind the bambo wall and they enter lidhi or sodho through the wall hole toward the girl intended, but now the youth who will directly be able to meet or toward to the girl which he intendes on the eve of celebrations to commemorate the birth of Prophet Muhammad Saw. In this case, the the parents and the community give the freedom of young people to become acquainted because it has become a

\footnotetext{
${ }^{38}$ Hilman, Hukum Perkawinan, 36.
}

Ta'aruf Locality: Integration Of Islamic Law And Customary Law Of The Phenomenon Using Tribe Gredoan In Banyuwangi tradition that is held every year the tradition Gredoan. And of course, must pay attention to the limits of reasonableness in accordance with the Islamic Syarī'ah.

In Customary Law in the tradition Gredoan has some function as follows:

1. As medium of matchmaking: using people in banyuwangi hope the children and their family who are still single can find a soul mate through this Gredoan tradition. And they believe that a mate that they get at night of Gredoan tradition will be blessed because it coincides with the celebration to commemorate the birth of Prophet Muhammad.

2. Avoiding free sex: people using banyuwangi hope this tradition will be a container for a mate search arena, the parents and the community give the freedom to their children to tease each other by the supervision of parents and community. So, as in the proposal process will avoid fornication/free sex.

3. As medium of silaturrahmi: using public confidence for gredoan tradition in banyuwangi can be a moment to gather with relatives and will increasethe family members at the same time.

In terms of the implementation of Islamic law, of Gredoan tradition is allowed, because in principle of Gredoan tradition is a process ta'aruf locality as a mate search arena, which has positive purpose ie, as a means towards marriage and strengthen silaturrahmi. And marriage 
is a suggestion to keep someone from fornication as is mentioned in the Qur'an. An-Nur (24): 30, also mentioned in the hadith:

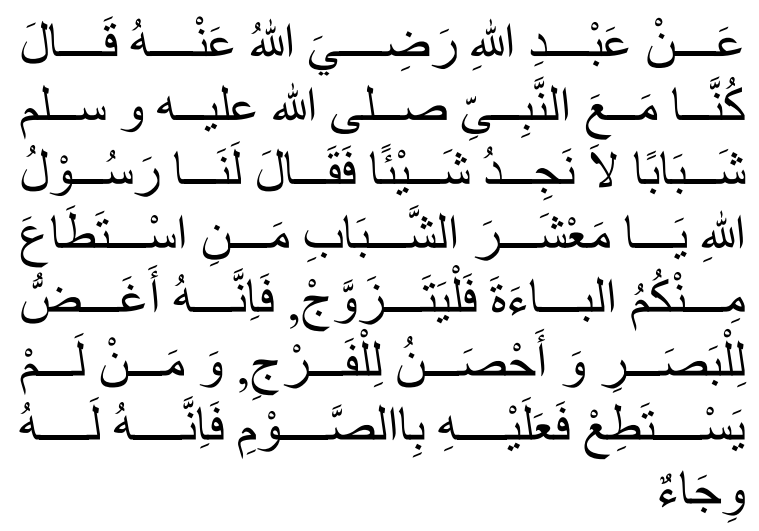

"From Abdullah r.a, he said: "We ever be together the Prophet and we include youths who do not have anything, then the Prophet said to us: "Oh youth, whoever of you is able to marry, then marry. Because actually married was keeping the eyes and maintain the pubic. And those who have not been able to get married, then it should be (he/she) fast because fasting is a fortress for him., 39

If it is peeled from concept of maṣlaḥah or maqāṣid, Abū Hāmid alGhazālī introduced the principle of munāsabah or suitability as one way to find ratiolegis in the texts. According to him, the legal reasons or 'illah can be found by way of a fully rational and logical. In the theory of al-Ghazālī, munāsabah principle is a texts reading techniques of the Qur'ān or Sunnah carefully to find the "spirit of the law" that underlie the laws of Syarīah. If the principles for the good and forbid the evil that is the purpose of the laws of the Syarī'ah then the munāsabah principle

3.

${ }^{39}$ Bukhari, Shahih Imam Bukhari Juz 7-9,

Ta'aruf Locality: Integration Of Islamic Law And Customary Law Of The Phenomenon Using Tribe should be in accordance with this principle. Because, at the end of Syarīah purpose is to bring the benefit of people in the world and in the hereafter. Here, then al- Ghazālī said that the purpose of Syarī'ah is to protect life, property, reason, religion and descent. Al- Ghazālī concluded the fifth goal of the five major crime in Islam who get firm punishment murder, theft, drinking wine, apostasy and adultery. ${ }^{40}$

Al- Ghazālī also explained that Syarī'ah purpose is diverse and layered according to its interests, which he classified according to the following taxonomy:

1. darūrah, namely human primary needs to be protected by the Syari' ah includes the five purpose as mentioned above (al-ușūl alkhamsah).

2. häjiyah, secondary needs of human, which is explained by al- Ghazāli as the only requirement needed to keep the peace and tranquility of society.

3. tahsiniyah, the level of needs that are solely to improve and expand (tahsin, tausi 'ah) implementation of the goals Syarī'ah purpose. ${ }^{41}$

Al- Syātịī explained that the origin purpose of God in creating the law is to protect the interests of human beings, the

\footnotetext{
${ }^{40}$ Al-Ghazālī, Syifā' al-Ghalīl fì al-Syabah wa 'l-Mukhīl wa Masālik al-Ta ' l̄̄l, diedit oleh Hamd al-Kabīsī (Baghdad: Maṭba'at al-Irsyād, 1971), hlm. 142-266. Lihat juga ikhtisarnya dalam Wael B. Hallaq, A History of Islamic Legal Theories: An Introduction to Sunn̄̄ Ușūl al-Fiqh (Cambridge: Cambridge University Press, 1997), 86-90.

41 Al-Ghazālī, Syifā̄' al-Ghalīl, hlm. 161.
} from Syarī'ah (hudīd), among others, 
temporal and the hereafter, in the three categories darūriyyāt, hājiyyāt, and tahsininyāt such as that proposed by alGhazālī earlier. According to him, " Syarī'ah created to [create] the benefit of mankind" (al-Syarī'atu wuḍi'at li-mașālih $a l$-'ibād). ${ }^{42}$ While Al- Ghazālī defined some terms so mașlahah can be used as a legal basis. The prerequisite is as follows, maslahah is the form of a darūriyyāt category. It means that to establish a benefit, the level of necessity must be considered whether to threaten the existence of the five key elements of beneficiaries or has not reached the limit. Secondly, maslahah is qat'i It means what is meant by the beneficiaries are actually believed to be the beneficiaries, not based on the assumption (based on speculation) only. Third, maslahah is kulli, it means the benefit applies in general or collective not individual. If it must be individualized, maslahah must in accordance maqāșid al-

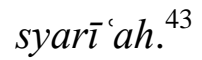

In terms of maqāṣid al-syarīah, gredoan custom is in conformity with the maqāșid al-syarīalah that inside their benefit, in this category, mașlahah mursalah is not mașlahah mu'tabaroh, because there is no texts that encourage it. Nor mașlahah mulghah because there is no texts that are contrary to the tradition, the other reason is because Gredoan tradition is a tradition that has been handed down are done by using people in Banyuwangi.

42 Al-Syāțibī, Al-Muwāfaqāt fì Ușūl alSyarīah, diedit oleh Muhammad 'Abd Allāh Darrāz, 4 jilid (Kairo: al-Maktabah al-Tijāriyyah alKubrā, t.t.), II: 67.

43 Abū Hāmid Al-Ghazālī, Al-Mustaşfā min 'Ilm al-Ușūl. (Beirut: Dār al-Fikr, t.t.), 4
Furthermore, this paper will explore the tradition Gredoan as ta'aruf process towards marriage if viewed in terms of al'urf. So, the researchers better see Gredoan tradition skew in terms of its legitimacy, it will be assessed al-'urf as Prophet historically as a legislator of Islam in the region Mecca and Medina, he adopted many of the local al-'urf. Most of al-'urf such as the enactment of the revelation of the Koran and the Hadith ${ }^{44}$ of the Prophet arguments in approving al- 'urf because $a l$ 'urf is able to provide the solutions that are expected to satisfy the needs of a particular community. But not all the arab tradition became part of Islamic Syarī'ah, some of them revised and modified ${ }^{45}$ and other partially canceled by the revelations of Allah. As the issue of usury and how to treat women in relation to marriage and inheritance. And the building of Islamic law from the time of the Prophet up to this day, can not be separated from al-'urf factor though al-urf is still a debate among jurists but their nisa be avoided because the lack of agreement on al-urf sole. Because most jurists realize that al- 'urf is a controversial topic in Islam debate.

As al-'urf in ta'aruf process toward marriages can be a part of the Islamic Syarī'ah, if there are irregularities that occurred in the Gredoan tradition of personal conducted by individuals, namely through a sophisticated communication tool youths do the teast to the opposite sex through social media before and when at

\footnotetext{
${ }^{44}$ Muhammad el Awa, The Place Of Custom ('Urf) in Islamic Legal Theory, 177-178

45 Ratno Lukito, Islamic Law and Adat Encounter; the experience of Indonesia (jakarta: Logos Wacana Ilmu,2001), 7
} 
the peak of gredoan tradition they choose to meet outside the home than come to woman home, it is actually not allowed based on Islamic law.

The reasons for are not being allowed because it is viewed of its implementation process is incompatible with the concept of ta'aruf in accordance with the Islamic Syarīah. While ta'aruf which defiance with the laws of Islam into the category of al-urf al-faşid, the tradition that is contrary to the arguments of the Syarī'ah or justify the prohibition or abolishes ${ }^{46}$ definitely should not be maintained, because the maintenance of the tradition will cause the damage.

To prevent the badness or things that are not desirable in the Gredoan tradition, it needs for improvement and streamlining of customary environment in the community. So that, the tradition that has been passed down through generations and became one of the assets of using banyuwangi culture of indigenous people is no longer conflict with Islamic Syarī'ah. In the study of Islam if there is a problem about 'custom /, the tradition or the Islamic law which is known as al- 'urf is to use the rules of figh

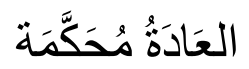

"Customs can be (considered) the law”

As has been described above that the tradition / al- 'urf which can be used as the legal basis is al- 'urf that is authentic, that it fulfills the requirements, namely:

\footnotetext{
${ }^{46}$ Muhammad Sidqi Ibn Ahmad al-Burnu, al- Wajiz Fi idhah Qawaid al-Fiqhal-Kulliyah, (Bairut: Muassasah al-Risalah, 1983), 157
}

Ta'aruf Locality: Integration Of Islamic Law And Customary Law Of The Phenomenon Using Tribe
1. The customary or al-'urf existed before the advent of case that will be assigned the legal and accepted common sense

2. 'The customary or al-'urf generally accepted and prevalent among people who are in the neighborhood 'of that custom or among most citizens.

3. Al-'urf is not contrary to that expressed clearly in a contract (transaction)

4. Not contradictory and neglect nash. $^{47}$

The purpose of the Customary law Integration and Islamic law in this paper is an attempt to fuse the Customary Law with Islamic law in view and examine the concept of ta'aruf in gredoan custom, in Islamic law, there is a term "al-'âdah alMuhakkamah" that gredoan custom can become a law, if gredoan custom and the custom has serious benefits as a basis laying Their customs, then the custom is good custom and worthy considered or enacted into law. In practice we can see the positive side, which is also strengthened with the concept of Interest Maqaşid Islamic law, so that, gredoan custom is allowed because there is integration between customary law and Islamic law is based on the rule of "al-'âdah alMuhakkamah".

\section{Conclusion}

Islam has ethics in the association and conduct introductions between man and

${ }^{47}$ Nasrun Haroen, Ushul Fiqh, 144 Gredoan In Banyuwangi 
woman before heading marriage. In the process of introduction according to the sharia in our society which is popularized by the term ta'aruf. Ta'aruf defined as a process to get to know the personality, family background, and religion of both parties aimed at finding a life partner. So, ta'aruf as a process towards marriage is an al-'urf which could serve as the basis or source of the development of Islamic law, the scholars agree that the laws established by al-'urf last for al- 'urf changed, then the legal power changed. In other words, that the provisions of Islamic law that builds on al-'urf do not have a lasting ordinance.

Gredoan is the tradition of matchmaker event occurring hereditary among the people in macan putih village using Kabat District of Banyuwangi, held annually in conjunction with the commemoration of the Birth of the Prophet Muhammad. Gredoan as al-'urf in ta'aruf process toward marriages can be a part of the Islamic shari'a because it acquires legitimacy by their Maqasid Overview of

\section{REFERENCE}

Abdullah,Ilham. 2003. Kado Buat Mempelai : Membentuk Keluarga Sakinah, Mawaddah Wa Rahmah. Yogyakarta : Absolut.

el Awa, Muhammad. The Place Of Custom ('Urf) in Islamic Legal Theory, 177178

Budi Setianto, Eko. Bunga Rampai Ritual Adat Dan Tradisi Masyarakat Banyuwangi . Banyuwangi : Dinas Kebudayaan Dan Pariwisata Kabupaten Banyuwangi.
Syari'ah in the form of raises welfare. which is based on the principle of "al-'âdat al-Muhakkamah".

Kualitatif dan R\&D. Bandung : Alfabeta.

Supranto. J. 2003. Metode Riset :Aplikasinya Dalam Pemasaran. Jakarta : RinekaCipta.

Al-Syāṭibī. Tt. Al-Muwāfaqāt fì Ușūl alSyarī'ah, diedit oleh Muhammad 'Abd Allāh Darrāz, 4 jilid .Kairo: alMaktabah al-Tijāriyyah al-Kubrā.

Pranowo, Bambang. 1998. Islam Factual Antara Tradisi Dan Relasi Kuasa .Yogyakarta: Adicita Karya Nusa.

Rahman.1996. Hudud dan Kewarisan.Jakarta : PT Raja Grafindo.

Tihami.2010. Fikih Munakahat.Jakarta : PT RajaGrafindo Persada.

Tirmidzi, Imam. 1983. al-Jami' as-Sahih wa Huwa Sunan Tirmidzi : Abwab anNikah. Beirut : Dar al-Fikr.

Bukhori. 1349. Shahih Bukhori. Mesir : Kementrian Abdurrahman Affandi Muhammad al-Azhar.

Creswell, John W. 2016. Research Design: PendekatanMetodeKualitatif, Kuantitatif dan Campuran, translated by Achmad Fawaid and Rianayati Kusmini Pancasari. Yogyakarta: PutakaPelajar.

Effendi, Satria. Ushul Fiqh. 2009.Jakarta : Kencana.

Ta'aruf Locality: Integration Of Islamic Law And Customary Law Of The Phenomenon Using Tribe Gredoan In Banyuwangi 
Al-Ghazālī, Abū Hāmid . tt. AlMustaşāmin 'Ilm al-Ușūl. Beirut: Dār al-Fikr.

1971. Syifä’’ al-Ghalīl fì alSyabah wa'l-Mukhīl wa Masālik alTa' 'lùl, diedit oleh Hamd al-Kabīsī. Baghdad: Maṭba at al-Irsyād.

Hadikususma, Hilman. 1999. Hukum Perkawinan Adat. Bandung: Citra Aditya Bakti.

Hakim, Rahmat. 2000. Hukum Perkawinan Islam. Bandung : CV Pustaka Setia.

Hallaq, Wael B. 1997. A History of Islamic Legal Theories: An Introduction to Sunnī Ușūl al-Fiqh . Cambridge: Cambridge University Press.

Karim Zaidan, karim. Tt. al- Wajiz Fi Ușūl al-Fiqh. kairo: Dhar al-Fikr.

Lukito, Retno. Islamic Law and Adat Encounter; the experience of Indonesia . Jakarta: Logos Wacana Ilmu.

Maftuhin ar-Raudli, M. 2015. Kaidah Fiqih Menjawab Problematika Sepanjang Zaman . Yogyakarta : Gava Media.
Miftahul jannah, Haney. 2014. A-Z Ta'aruf, Khitbah, Nikah, \& Talak Bagi Muslimah .Jakarta : PT Grasindo.

Muhammad Sidqi Ibn Ahmad al-Burnu. 1983. al- Wajiz Fi idhah Qawaid alFiqhal-Kulliyah. Bairut: Muassasah alRisalah.

Pranoto,Dwi. 2014. Membicarakan Seni Dan Sastra Banyuwangi.Bali : Pustaka Larasan.

Pranowo, Bambang. 1998. Islam Factual Antara Tradisi Dan Relasi Kuasa .Yogyakarta: Adicita Karya Nusa.

Al-Qaradhawi,Yusuf. 1995. Fatwa-fatwa Kontemporer Jilid 2.Jakarta : Gema Insani.

Qayyim al-Jauziyah, Ibnu. 1995. Jangan Dekati Zina.Jakarta : Pustaka Amani.

Syafe'i, Rahcmat. 2007. Ilmu Ushul Fiqh. Bandung : CV Pustaka Setia.

Syarifuddin,Amir. 2011. Ushul Fiqh Jilid 2 . Jakarta : Kencana.

Sugiyono. 2010. Metode Penelitian Pendidikan : Pendekatan Kuantitatif, 